\title{
Nonaromatic Amidine Derivatives as Acylation Catalysts
}

Vladimir B. Birman,* Ximin Li and Zhenfu Han

A contribution from the Department of Chemistry, Washington University, Campus Box 1134, One Brookings Drive, Saint Louis, Missouri 63130

SUPPORTING INFORMATION: Experimental procedures (8 pages), ${ }^{1} \mathrm{H}$ NMR and ${ }^{13} \mathrm{C}$ NMR spectra (18 pages).

\section{EXPERIMENTAL PART.}

1. General. All reagents were obtained commercially and used as received unless otherwise specified. Catalysts $3,^{7 \mathrm{a}} \mathbf{4},{ }^{7 \mathrm{a}} \mathbf{5},{ }^{7 \mathrm{~b}} \mathbf{6},{ }^{7 \mathrm{c}}$ and $\mathbf{7}^{7 \mathrm{c}}$ were prepared as previously described.

Solvents used for chromatography were ACS or HPLC grade. Reactions were monitored by thin layer chromatography (TLC) using EM Science 60F silica gel plates. Flash column chromatography was performed over ICN Ecochrom silica gel $(32-63 \mu \mathrm{m})$. Deuterated chloroform used for catalytic activity measurements was obtained from Aldrich and was freshly distilled from anhydrous potassium carbonate. N,N-diisopropylethylamine was distilled from potassium hydroxide pellets. ${ }^{1} \mathrm{H}$ NMR and ${ }^{13} \mathrm{C}$ NMR spectra were recorded on a Unity $300 \mathrm{MHz}$ Varian spectrometer. The chemical shifts are reported as $\delta$ values (ppm) relative to TMS using residual $\mathrm{CHCl}_{3}$ peak $(7.26 \mathrm{ppm})$ as the reference. High-Resolution mass spectral analyses were performed at Washington University MS Center on a Kratos MS-50TA spectrometer using electron impact (EI) or fast atom bombardment (FAB) methods. Infrared spectra were recorded on a Perkin-Elmer Spectrum Bx FTIR spectrophotometer using potassium bromide plates. Melting points were measured on a Thomas-Hoover capillary melting point apparatus.

\section{Preparation of Bicyclic Amidines}

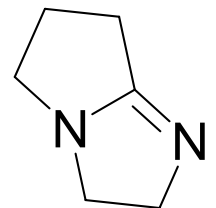

2,5,6,7-Tetrahydro-3H-Pyrrolo[1,2-a]imidazole (10).

A combination of two literature procedures was used. ${ }^{11,15}$ General Procedure: To a solution of aminoethanol hydrochloride $(0.975 \mathrm{~g}, 10.0 \mathrm{mmol})$ in $5 \mathrm{~mL}$ of methanol was added 2-methoxypyrroline ${ }^{15}(1.090 \mathrm{~g}, 11.0 \mathrm{mmol})$ at room temperature under nitrogen. The mixture was stirred overnight. The solvent was evaporated and the residue was dissolved in $20 \mathrm{~mL}$ of chloroform. Thionyl chloride $(1.785 \mathrm{~g}, 15.0 \mathrm{mmol})$ was added dropwise. The mixture was heated gradually to $65^{\circ} \mathrm{C}$, stirred at this temperature for $1 \mathrm{~h}$, allowed to cool down, and treated with a few drops of methanol to quench the excess thionyl chloride. The solution was rotary evaporated, the residue was basified with $20 \%$ aqueous $\mathrm{NaOH}$ solution and extracted with $\mathrm{CH}_{2} \mathrm{Cl}_{2}$. The organic phase was dried over anhydrous $\mathrm{Na}_{2} \mathrm{SO}_{4}$ and evaporated to dryness. Ethanol $(10 \mathrm{~mL})$ was added to the residue. The solution was heated under reflux for $2 \mathrm{~h}$ under nitrogen. After concentration, the residue was basified with 20\% $\mathrm{NaOH}$ and extracted with $\mathrm{CH}_{2} \mathrm{Cl}_{2}$. The organic phase was dried over anhydrous $\mathrm{Na}_{2} \mathrm{SO}_{4}$ and concentrated on a rotary evaporator. Distillation under reduced pressure gave the pure product $\left(0.265 \mathrm{~g}, 24 \%\right.$ yield) as a colorless liquid, bp $80{ }^{\circ} \mathrm{C} / 10 \mathrm{mmHg} .{ }^{1} \mathbf{H} \mathbf{~ N M R}\left(300 \mathrm{MHz}, \mathrm{CDCl}_{3}\right) \delta$ $4.03(\mathrm{t}, J=8.7 \mathrm{~Hz}, 2 \mathrm{H}), 3.12(\mathrm{t}, J=8.7 \mathrm{~Hz}, 2 \mathrm{H}), 2.98(\mathrm{~m}, 2 \mathrm{H}), 2.30(\mathrm{~m}, 4 \mathrm{H}) ;{ }^{13} \mathbf{C} \mathbf{N M R}(75 \mathrm{~Hz}$, 
$\left.\mathrm{CDCl}_{3}\right) \delta 176.48,60.82,49.80,46.97,25.24,22.22$; IR (film, $\mathrm{cm}^{-1}$ ) 2926, 2851, 1645; LRMS (EI) calculated for $\mathrm{C}_{6} \mathrm{H}_{10} \mathrm{~N}_{2} \mathrm{~m} / \mathrm{z}: 110.08$, found: 110.1 . Note: this compound rapidly decomposes on storage.

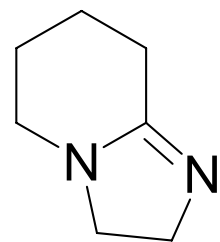

\section{2,3,5,6,7,8-Hexahydro-imidazo[1,2-a]pyridine (11).}

Prepared according to the general procedure starting with O-methylvalerolactim ${ }^{16}$ and aminoethanol hydrochloride. Distillation afforded the pure product in $16 \%$ yield, bp $88{ }^{\circ} \mathrm{C} / 10 \mathrm{mmHg} .{ }^{1} \mathbf{H}$ NMR $\left(300 \mathrm{MHz}, \mathrm{CDCl}_{3}\right) \quad \delta 3.63(\mathrm{t}, J=9.3 \mathrm{~Hz}$, $2 \mathrm{H}), 3.17(\mathrm{t}, \mathrm{J}=9.3 \mathrm{~Hz}, 2 \mathrm{H}), 2.97(\mathrm{t}, J=6.0 \mathrm{~Hz}, 2 \mathrm{H}), 2.36(\mathrm{t}, J=6.0 \mathrm{~Hz}, 2 \mathrm{H}), 1.80$ $(\mathrm{m}, 2 \mathrm{H}), 1.68(\mathrm{~m}, 2 \mathrm{H}) ;{ }^{13} \mathrm{C}$ NMR $\left(75 \mathrm{~Hz}, \mathrm{CDCl}_{3}\right) \delta 164.46,51.86,48.21,26.09,23.54,21.97$; IR (film, cm ${ }^{-1}$ ) 2944, 2861, 1619; HRMS (EI) calculated for $\mathrm{C}_{7} \mathrm{H}_{12} \mathrm{~N}_{2} \mathrm{~m} / \mathrm{z}:$ 124.1000, found: 124.0997.

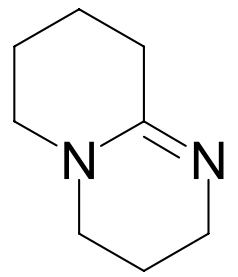

\section{3,4,6,7,8,9-Hexahydro-2H-pyrido[1,2-a]pyrimidine (12).}

Prepared according to the general procedure starting with O-methylvalerolactim and 3-aminopropanol hydrochloride. Distillation gave the pure product in $44 \%$ yield, bp $110{ }^{\circ} \mathrm{C} / 10 \mathrm{mmHg} .{ }^{1} \mathbf{H}$ NMR $\left(300 \mathrm{MHz}, \mathrm{CDCl}_{3}\right) \delta 3.32(\mathrm{t}, J=6.0 \mathrm{~Hz}$, $2 \mathrm{H}), 3.07(\mathrm{t}, J=6.0 \mathrm{~Hz}, 2 \mathrm{H}), 3.01(\mathrm{t}, J=6.0 \mathrm{~Hz}, 2 \mathrm{H}), 2.29(\mathrm{t}, J=6.0 \mathrm{~Hz}, 2 \mathrm{H})$, $1.60 \sim 1.90(\mathrm{~m}, 6 \mathrm{H}) ;{ }^{13} \mathrm{C}$ NMR $\left(75 \mathrm{~Hz}, \mathrm{CDCl}_{3}\right) \delta 155.48,50.65,47.89,43.92$, 32.56, 23.84, 21.68, 21.59; IR (film, $\left.\mathrm{cm}^{-1}\right)$ 2951, 2875, 1652; HRMS (EI) calculated for $\mathrm{C}_{8} \mathrm{H}_{14} \mathrm{~N}_{2} \mathrm{~m} / \mathrm{z}: 138.1157$, found: 138.1144 .

\section{Preparation of Bicyclic Isothioureas}

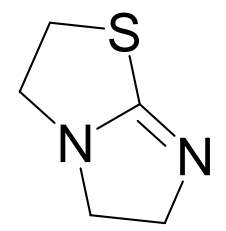

\section{2,3,5,6-Tetrahydroimidazo [2,1-b]thiazole (13)}

A modified literature procedure was used. ${ }^{12 \mathrm{~b}}$ General Procedure: To a mixture of 2-imidazolidinethione $(5.108 \mathrm{~g}, 50.0 \mathrm{mmol})$ and $\mathrm{Na}_{2} \mathrm{CO}_{3}(6.0 \mathrm{~g})$ were added absolute ethanol $(50 \mathrm{~mL})$ and 1,2-dibromoethane $(4.5 \mathrm{~mL}, 52.0 \mathrm{mmol})$. The mixture was refluxed for $3 \mathrm{~h}$, and then concentrated under vacuum. The evaporation residue was basified with $20 \% \mathrm{NaOH}$ to $\mathrm{pH} 14$. The resulting mixture was extracted three times with $\mathrm{CH}_{2} \mathrm{Cl}_{2}$. The organic extract was dried over $\mathrm{Na}_{2} \mathrm{SO}_{4}$ and concentrated under vacuum. Flash chromatography (50\% EtOAc, 5\% $\mathrm{Et}_{3} \mathrm{~N}, 45 \%$ Hexane) afforded $3.76 \mathrm{~g}$ of the title compound (59\% yield). ${ }^{1} \mathbf{H}$ NMR $\left(300 \mathrm{MHz}, \mathrm{CDCl}_{3}\right): \delta 3.93(\mathrm{t}, J=8.4 \mathrm{~Hz}, 2 \mathrm{H}), 3.42(\mathrm{t}, J=6.4$ $\mathrm{Hz}, 2 \mathrm{H}), 3.06(\mathrm{t}, J=6.4 \mathrm{~Hz}, 2 \mathrm{H}), 3.02(\mathrm{t}, J=8.4 \mathrm{~Hz}, 2 \mathrm{H}) ;{ }^{13} \mathrm{C}$ NMR $\left(75 \mathrm{MHz}, \mathrm{CDCl}_{3}\right): \delta 174.1$, 61.7, 50.6, 48.8, 34.1; IR (film, $\mathrm{cm}^{-1}$ ) 1596, 1193; MS: HR-FAB calculated for $\mathrm{C}_{5} \mathrm{H}_{9} \mathrm{~N}_{2} \mathrm{~S}$ $\left(\mathrm{M}+\mathrm{H}^{+}\right) \mathrm{m} / \mathrm{z}: 129.0486$, found: 129.0488 .

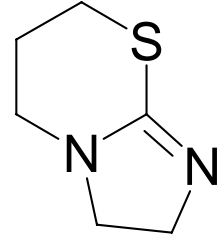

\section{2,3,6,7-Tetrahydroimidazo [2,1-b]thiazine (14)}

Prepared according to the general procedure, starting with 2-imidazolidinethione and 1,3-dibromopropane. 73\% yield after chromotography $\left(5 \% \mathrm{MeOH}, 2 \% \mathrm{Et}_{3} \mathrm{~N}\right.$ and $\left.93 \% \mathrm{CH}_{2} \mathrm{Cl}_{2}\right)$. ${ }^{1} \mathbf{H}$ NMR $\left(300 \mathrm{MHz}, \mathrm{CDCl}_{3}\right): \delta 3.64(\mathrm{t}, J=9.1 \mathrm{~Hz}, 2 \mathrm{H}), 3.26$ (t, $J=9.1 \mathrm{~Hz}, 2 \mathrm{H}), 3.14(\mathrm{t}, J=5.6 \mathrm{~Hz}, 2 \mathrm{H}), 2.90(\mathrm{t}, J=5.6 \mathrm{~Hz}, 2 \mathrm{H}), 2.17$ (app. quintet, $J=5.6 \mathrm{~Hz}, 2 \mathrm{H}) ;{ }^{13} \mathbf{C}$ NMR $\left(75 \mathrm{MHz}, \mathrm{CDCl}_{3}\right): \delta 159.0,52.0,51.4,46.9,26.6$, 23.9; IR (film, $\left.\mathrm{cm}^{-1}\right)$ 1560, 1270; MS: HR-FAB calculated for $\mathrm{C}_{6} \mathrm{H}_{11} \mathrm{~N}_{2} \mathrm{~S}\left(\mathrm{M}+\mathrm{H}^{+}\right) \mathrm{m} / \mathrm{z}$ : 143.0643, found: 143.0642 . 


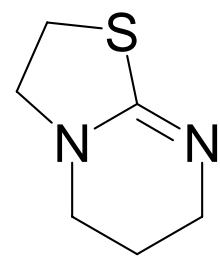

\section{2,3,6,7-Tetrahydro-5H-thiazolo [3,2-a] pyrimidine (15)}

Prepared according to the general procedure, starting with 3,4,5,6-tetrahydro-2pyrimidinethiol and 1,2-dibromoethane. $70 \%$ yield after chromotography $(5 \%$ $\mathrm{MeOH}, 5 \% \mathrm{Et}_{3} \mathrm{~N}$ and $\left.90 \% \mathrm{CH}_{2} \mathrm{Cl}_{2}\right)$. ${ }^{1} \mathbf{H}$ NMR $\left(300 \mathrm{MHz}, \mathrm{CDCl}_{3}\right): \delta 3.44$ (t, $J=$ $6.9 \mathrm{~Hz}, 2 \mathrm{H}), 3.32$ (t, $J=5.8 \mathrm{~Hz}, 2 \mathrm{H}), 3.17$ (t, $J=5.8 \mathrm{~Hz}, 2 \mathrm{H}), 3.04$ (t, $J=6.9 \mathrm{~Hz}$, 2H), 1.79 (app. quintet, $J=5.8 \mathrm{~Hz}, 2 \mathrm{H}) ;{ }^{13} \mathbf{C}$ NMR $\left(75 \mathrm{MHz}, \mathrm{CDCl}_{3}\right): \delta 160.2$, 53.9, 45.5, 44.7, 26.1, 20.8; IR (film, $\mathrm{cm}^{-1}$ ) 1615, 1353, 1288; MS: HR-FAB calculated for $\mathrm{C}_{6} \mathrm{H}_{11} \mathrm{~N}_{2} \mathrm{~S}\left(\mathrm{M}+\mathrm{H}^{+}\right) \mathrm{m} / \mathrm{z}: 143.0643$, found: 143.0618 .

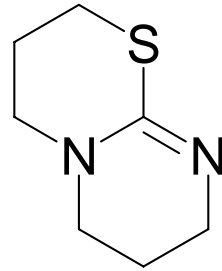

\section{3,4,7,8-Tetrahydro-2H,6H-pyrimido [2,1-b]-[1,3]-thiazine (16)}

The general procedure was modified slightly in this case. A mixture of $3,4,5,6-$ tetrahydro-2-pyrimidinethiol $(1.166 \mathrm{~g}, 10.0 \mathrm{mmol}), \mathrm{Na}_{2} \mathrm{CO}_{3}(1.2 \mathrm{~g})$, absolute ethanol $(10 \mathrm{~mL})$ and 1,3-dibromopropane $(1.07 \mathrm{~mL}, 11.0 \mathrm{~mol})$ was heated at 60 ${ }^{\circ} \mathrm{C}$ for $5 \mathrm{~h}$. The reaction mixture was filtered through Celite and concentrated under vacuum. The residue was basified with $20 \% \mathrm{NaOH}$ to $\mathrm{pH} 14$ and immediately extracted with $\mathrm{CH}_{2} \mathrm{Cl}_{2}$. Evaporation of the solvent gave the product in $99 \%$ yield. Note: The crude product was ca. $95 \%$ pure and was used directly for catalytic activity measurements, since attempted chromatography led to partial decomposition. ${ }^{1} \mathbf{H}$ NMR (300 $\mathrm{MHz}, \mathrm{CDCl}_{3}$ ): $\delta 3.31$ (t, $\left.J=5.8 \mathrm{~Hz}, 2 \mathrm{H}\right), 3.12(\mathrm{t}, J=6.0 \mathrm{~Hz}, 2 \mathrm{H}), 3.08$ (t, $\left.J=5.8 \mathrm{~Hz}, 2 \mathrm{H}\right), 2.85(\mathrm{t}$, $J=5.8 \mathrm{~Hz}, 2 \mathrm{H}), 2.07\left(\mathrm{tt}, J_{1}=6.0 \mathrm{~Hz}, J_{2}=5.8 \mathrm{~Hz}, 2 \mathrm{H}\right), 1.84\left(\mathrm{tt}, J_{1}=6.0 \mathrm{~Hz}, J_{2}=5.8 \mathrm{~Hz}, 2 \mathrm{H}\right) ;{ }^{13} \mathbf{C}$ NMR $\left(75 \mathrm{MHz}, \mathrm{CDCl}_{3}\right): \delta 152.4,50.5,49.8,27.6,24.8,22.6$; IR (film, $\left.\mathrm{cm}^{-1}\right)$ 1587, 1434, 1302; MS: HR-FAB calculated for $\mathrm{C}_{7} \mathrm{H}_{12} \mathrm{~N}_{2} \mathrm{~S}\left(\mathrm{M}+\mathrm{H}^{+}\right) \mathrm{m} / \mathrm{z}: 157.0799$, found: 157.0783 .

\section{Preparation of Okamoto's catalyst (19) ${ }^{11 a}$}

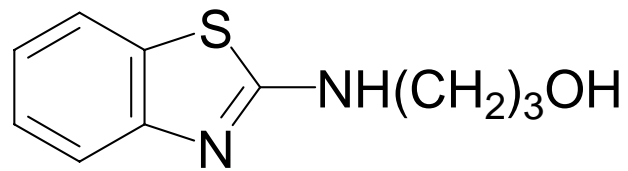

\section{3-(2-benzothiazolylamino)-1-Propanol.}

A $30-\mathrm{mL}$ pressure tube charged with 2chlorobenzothiazole $(0.209 \mathrm{~g}, 1.23 \mathrm{mmol})$, 3-amino-1propanol $(94 \mu \mathrm{L}, 1.23 \mathrm{mmol}), i-\mathrm{Pr}_{2} \mathrm{NEt}(0.33 \mathrm{~mL}, 1.89$ $\mathrm{mmol}$ ) and a stir bar was flushed with nitrogen several times, stoppered and heated at $110 \pm 5{ }^{\circ} \mathrm{C}$ for 13 hours. After cooling the tube to $30-40^{\circ} \mathrm{C}$, the viscous reaction mixture was treated with 5 $\mathrm{mL}$ of $\mathrm{CH}_{2} \mathrm{Cl}_{2}$ and left at room temperature to dissolve. The diluted reaction mixture was applied directly to a chromatographic column (10\% isopropanol in $\left.\mathrm{CH}_{2} \mathrm{Cl}_{2}\right)$ to afford $0.196 \mathrm{~g}$ of white solid (76\% yield). ${ }^{1} \mathbf{H}$ NMR $(300 \mathrm{MHz}, \mathrm{CD} 3 \mathrm{OD}): \delta 7.52(\mathrm{~d}, J=7.7 \mathrm{~Hz}, 1 \mathrm{H}), 7.41(\mathrm{~d}, 8.2 \mathrm{~Hz}$, $1 \mathrm{H}), 7.21(\mathrm{t}, J=8.2 \mathrm{~Hz}, 1 \mathrm{H}), 7.01(\mathrm{t}, J=7.7 \mathrm{~Hz}, 1 \mathrm{H}), 3.67(\mathrm{t}, J=6.0 \mathrm{~Hz}, 2 \mathrm{H}), 3.50(\mathrm{t}, J=6.9$ $\mathrm{Hz}, 2 \mathrm{H}), 1.86(\mathrm{tt}, J 1=6.0 \mathrm{~Hz}, J 2=6.9 \mathrm{~Hz}, 2 \mathrm{H}) ;{ }^{13} \mathbf{C}$ NMR $(75 \mathrm{MHz}, \mathrm{CD} 3 \mathrm{OD}): \delta 169.5,153.3$, 131.2, 127.0 122.7, 121.9, 119.0, 60.4, 42.6, 33.3; IR (film, cm ${ }^{-1}$ ) 1570, 1550, 1446; MS: HRFAB calculated for $\mathrm{C}_{10} \mathrm{H}_{12} \mathrm{~N}_{2} \mathrm{OSLi}\left(\mathrm{M}+\mathrm{Li}^{+}\right) \mathrm{m} / \mathrm{z}$ : 215.0830 , found: 215.0866 ; mp 123-123.5 ${ }^{\circ} \mathrm{C}$.

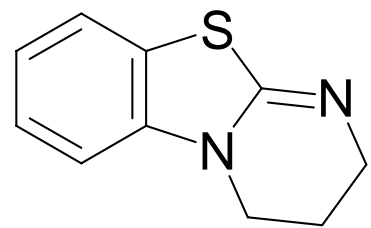

\section{3,4-dihydro-2H-pyrimido [2,1-b] benzothiazole (19)}

A solution of $50 \mathrm{mg}(0.24 \mathrm{mmol})$ of 3-(2-benzothiazolylamino)-1Propanol in anhydrous $\mathrm{CH}_{2} \mathrm{Cl}_{2}(2.4 \mathrm{~mL})$ was cooled to $0{ }^{\circ} \mathrm{C}$ under $\mathrm{N}_{2}$ atmosphere and treated with $\mathrm{NEt}_{3}(0.1 \mathrm{~mL}, 0.72 \mathrm{mmol})$ followed by $\mathrm{MsCl}$ $(0.028 \mathrm{~mL}, 0.36 \mathrm{mmol})$. The mixture was stirred at $0{ }^{\circ} \mathrm{C}$ for $1 \mathrm{~h}$ and then warmed up to room temperature. Methanol $(0.05 \mathrm{~mL})$ was then added to quench the excess $\mathrm{MsCl}$. $\mathrm{NEt}_{3}(0.4 \mathrm{~mL})$ was added and the mixture was refluxed overnight. The cooled mixture was 
washed with a small amount of water, dried over $\mathrm{Na}_{2} \mathrm{SO}_{4}$ and rotary evaporated. The crude product was purified by chromatography ( $5 \% \mathrm{i}-\mathrm{PrOH}, 1 \% \mathrm{NEt}_{3} /$ hexanes) to give $40.8 \mathrm{mg}$ of white solid (92\% yield). ${ }^{1} \mathbf{H}$ NMR $\left(300 \mathrm{MHz}, \mathrm{CDCl}_{3}\right): \delta 7.22(\mathrm{~d}, J=7.7 \mathrm{~Hz}, 1 \mathrm{H}), 7.14(\mathrm{t}, 8.0 \mathrm{~Hz}$, $1 \mathrm{H}), 6.93(\mathrm{t}, J=7.7 \mathrm{~Hz}, 1 \mathrm{H}), 6.67(\mathrm{~d}, J=8.0 \mathrm{~Hz}, 1 \mathrm{H}), 3.70(\mathrm{t}, J=6.0 \mathrm{~Hz}, 2 \mathrm{H}), 3.52(\mathrm{t}, J=5.5$ $\mathrm{Hz}, 2 \mathrm{H}), 1.97\left(\mathrm{tt}, J_{1}=5.5 \mathrm{~Hz}, J_{2}=6.0 \mathrm{~Hz}, 2 \mathrm{H}\right) ;{ }^{13} \mathbf{C}$ NMR $\left(75 \mathrm{MHz}, \mathrm{CDCl}_{3}\right): \delta 157.7,140.9$, 125.8, 122.3, 121.7, 121.5, 107.2, 45.6, 41.9, 19.7; IR (film, $\left.\mathrm{cm}^{-1}\right)$ 1299, 1240, 1187; MS: HRFAB calculated for $\mathrm{C}_{10} \mathrm{H}_{11} \mathrm{~N}_{2} \mathrm{~S}\left(\mathrm{M}+\mathrm{H}^{+}\right) \mathrm{m} / \mathrm{z}$ : 191.0643 , found: 191.0663 ; mp $122-123{ }^{\circ} \mathrm{C}$.

\section{Catalytic activity measurements}

Stock solution M. Methanol (1.25 mmol, $40 \mathrm{mg}, 51 \mu \mathrm{L})$ and $\mathrm{N}, \mathrm{N}$-diisopropylethylamine $(1.25 \mathrm{mmol}, 162 \mathrm{mg}, 218 \mu \mathrm{L})$ were diluted with deuterated chloroform in a $5 \mathrm{~mL}$ volumetric flask (final concentration: $0.25 \mathrm{M} \mathrm{MeOH}, 0.25 \mathrm{M} i-\mathrm{Pr}_{2} \mathrm{NEt}$ ).

Stock solution PE1. ( \pm )-phenylethanol (12.5 mmol, $1.53 \mathrm{~g}, 1.50 \mathrm{~mL})$ and N,Ndiisopropylethylamine (12.5 mmol, $1.62 \mathrm{~g}, 2.18 \mathrm{~mL})$ were diluted with deuterated chloroform in a $5 \mathrm{~mL}$ volumetric flask (final concentration: $2.5 \mathrm{M} \mathrm{PhCH}(\mathrm{OH}) \mathrm{Me}, 2.5 \mathrm{M}$ i$\left.\mathrm{Pr}_{2} \mathrm{NEt}\right)$.

Stock solution PE2. Prepared by diluting a $0.50 \mathrm{~mL}$ aliquot of Stock solution $\mathbf{P 1}$ to $5.0 \mathrm{~mL}$ with deuterated chloroform in a volumetric flask (final concentration: $0.25 \mathrm{M}$ $\mathrm{PhCH}(\mathrm{OH}) \mathrm{Me}, 0.25 \mathrm{M}$ i- $\left.\mathrm{Pr}_{2} \mathrm{NEt}\right)$.

Stock solution CH2. cyclohexanol (1.25 mmol, $0.125 \mathrm{~g}, 132 \mu \mathrm{L})$ and $\mathrm{N}, \mathrm{N}-$ diisopropylethylamine $(1.25 \mathrm{mmol}, 0.162 \mathrm{~g}, 0.22 \mathrm{~mL})$ were diluted with deuterated chloroform in a $5 \mathrm{~mL}$ volumetric flask (final concentration: $0.25 \mathrm{M}$ cyclohexanol, $0.25 \mathrm{M}$ i$\mathrm{Pr}_{2} \mathrm{NEt}$ ).

Stock solution MB2. 3-methyl-2-butanol (1.25 mmol, $0.110 \mathrm{~g}, 135 \mu \mathrm{L})$ and N,Ndiisopropylethylamine $(1.25 \mathrm{mmol}, 0.162 \mathrm{~g}, 0.22 \mathrm{~mL})$ were diluted with deuterated chloroform in a $5 \mathrm{~mL}$ volumetric flask (final concentration: $0.25 \mathrm{M}$ 3-methyl-2-butanol, 0.25 $\left.\mathrm{M} i-\mathrm{Pr}_{2} \mathrm{NEt}\right)$.

Stock solution A1. Acetic anhydride (12.5 mmol, $1.28 \mathrm{~g}, 1.18 \mathrm{~mL})$ was diluted with deuterated chloroform in a $5 \mathrm{~mL}$ volumetric flask (final concentration: $2.5 \mathrm{M} \mathrm{Ac}_{2} \mathrm{O}$ ).

Stock solution A2. Prepared by diluting a $0.50 \mathrm{~mL}$ aliquot of Stock solution A1 to $5.0 \mathrm{~mL}$ with deuterated chloroform in a volumetric flask (final concentration: $0.25 \mathrm{M} \mathrm{Ac}_{2} \mathrm{O}$ ).

Stock solution C1 (primary, $0.25 \mathrm{M}$ ). Prepared by dissolving $0.25 \mathrm{mmol}$ of each catalyst (1, $2,3,4,5,6,7,8,9,10,11,12,16,1718,19$ and 22) in deuterated chloroform in a $1.0 \mathrm{~mL}$ volumetric test tube and bringing the volume to the mark.

Stock solution C2 $(0.050 \mathrm{M})$. Prepared by diluting a $0.20 \mathrm{~mL}$ aliquot of the primary stock solution $\mathbf{C 1}$ with deuterated chloroform to $1.0 \mathrm{~mL}$ in a volumetric test tube. 
Stock solution C3 $(0.025 \mathrm{M})$. Prepared by diluting a $0.20 \mathrm{~mL}$ aliquot of the primary stock solution $\mathbf{C 1}$ with deuterated chloroform to $2.0 \mathrm{~mL}$ in a volumetric test tube.

Stock solution C4 $(0.005 \mathrm{M})$. Prepared by diluting a $0.10 \mathrm{~mL}$ aliquot of the primary stock solution $\mathbf{C 1}$ with deuterated chloroform to $5.0 \mathrm{~mL}$ in a volumetric flask.

Stock solution C5 $(0.0005 \mathrm{M})$. Prepared by diluting a $0.50 \mathrm{~mL}$ aliquot of the $0.005 \mathrm{M}$ stock solution $\mathbf{C 4}$ with deuterated chloroform to $5 \mathrm{~mL}$ in a volumetric flask.

\section{Methanol test.}

Stock solution of each catalyst $(0.10 \mathrm{~mL}, \mathbf{C} 3$ for $5 \mathrm{~mol} \%$ or C5 for $0.1 \mathrm{~mol} \%$ catalyst loadings, respectively, or pure $\mathrm{CDCl}_{3}$ for a blank) was mixed with stock solution $\mathbf{M}(0.20$ $\mathrm{mL})$ in an NMR tube. Stock solution $\mathbf{A 2}(0.2 \mathrm{~mL})$ was rapidly injected, the tube was shaken to ensure complete mixing and immediately inserted into an NMR spectrometer. The conversion was measured by comparing the integrals of the peaks of methanol $(\mathrm{s}, \delta 3.4)$ and methyl acetate (s, $\delta 3.6)$. After the initial measurement, the conversion was checked at appropriate time intervals and plotted versus time. The $t_{1 / 2}$ value was determined from the resulting graph.

\section{Secondary alcohol test.}

1. At $1 \mathrm{M}$ concentration of the reactants. Performed analogously to the methanol test using $0.10 \mathrm{~mL}$ of the appropriate stock solution of each catalyst (C1 for $5 \mathrm{~mol} \%$, C2 for 1 mol\%, or C4 for $0.1 \mathrm{~mol} \%$ catalyst loadings, respectively), $0.20 \mathrm{~mL}$ of PE1 and $0.2 \mathrm{~mL}$ of A1. The conversion was monitored by comparing the integrals of the peaks of phenylethanol $(\mathrm{q}, \delta 4.8)$ and phenethyl acetate $(\mathrm{q}, \delta 5.6)$.

2. At $0.1 \mathrm{M}$ concentration of the reactants and $1 \mathrm{~mol} \%$ catalyst loadings. Performed analogously, using $0.10 \mathrm{~mL}$ of the $\mathbf{C} 4$ stock solution of each catalyst, $0.20 \mathrm{~mL}$ of PE2 and $0.2 \mathrm{~mL}$ of A2.

3. At $0.1 \mathrm{M}$ concentration of the reactants and $5 \mathrm{~mol} \%$ catalyst loadings. Performed analogously, using $0.10 \mathrm{~mL}$ of the C3 stock solution of each catalyst (DMAP 1, THTP 15 or DHPB 19), $0.20 \mathrm{~mL}$ of the substrate stock solution (PE2, CH2 or MB2) and $0.2 \mathrm{~mL}$ of A2.

\section{\% Conversion vs. time plots}

Reaction progress was monitored by ${ }^{1} \mathrm{H}$ NMR at room temperature for the following substrates: methanol $(0.1 \mathrm{M}$ reactants, $0.1 \mathrm{~mol} \%$ catalyst), 1-phenylethanol $(0.1 \mathrm{M}$ reactants, 1 $\mathrm{mol} \%$ catalyst), cyclohexanol ( $0.1 \mathrm{M}$ reactants, $5 \mathrm{~mol} \%$ catalyst), and 3-methyl-2-butanol ( 0.1 $\mathrm{M}$ reactants, 5 mol \% catalyst) in the presence of DMAP 1, THTP 15 and DHPB 19. The \% conversion data were plotted versus time. 

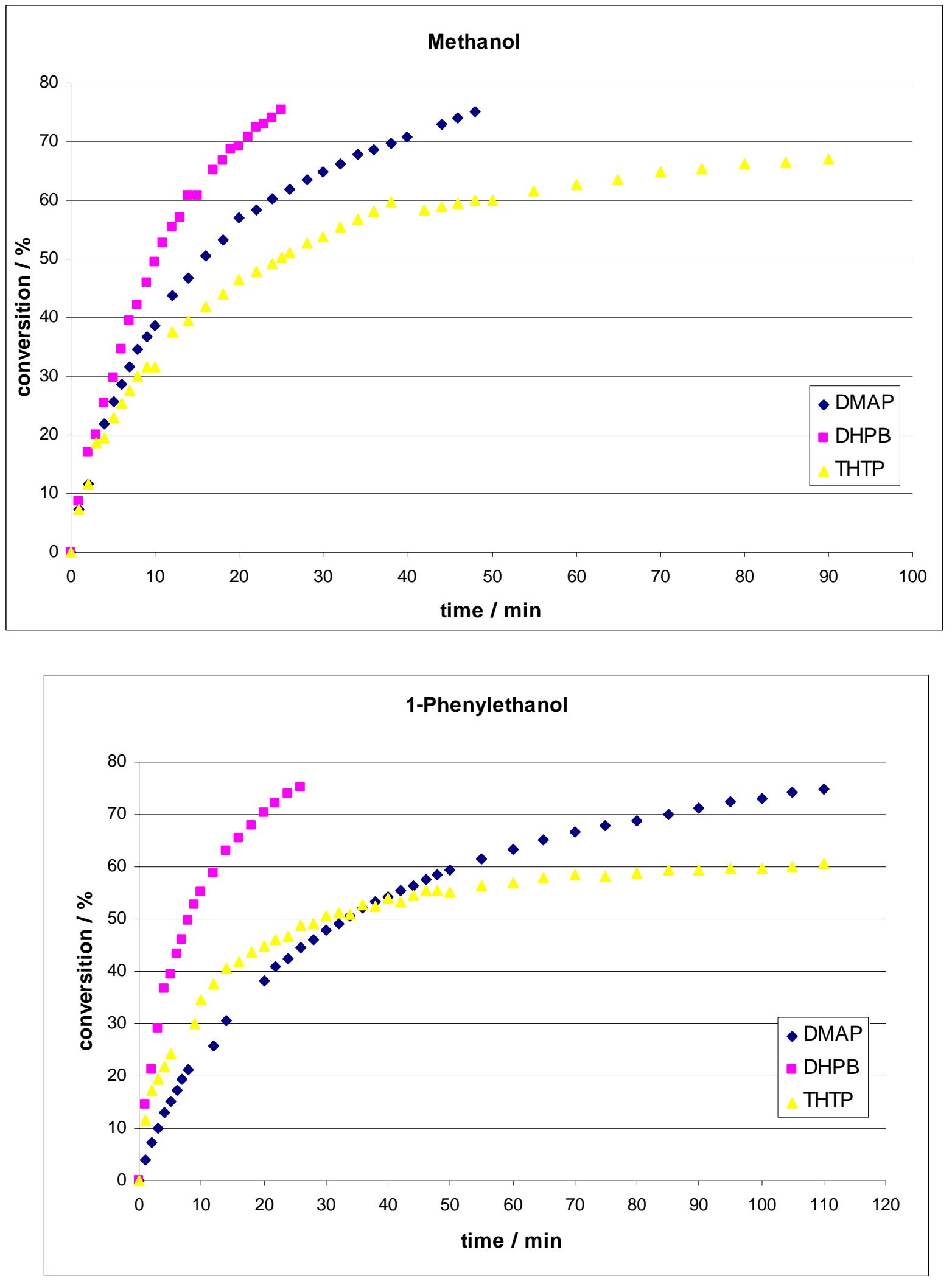

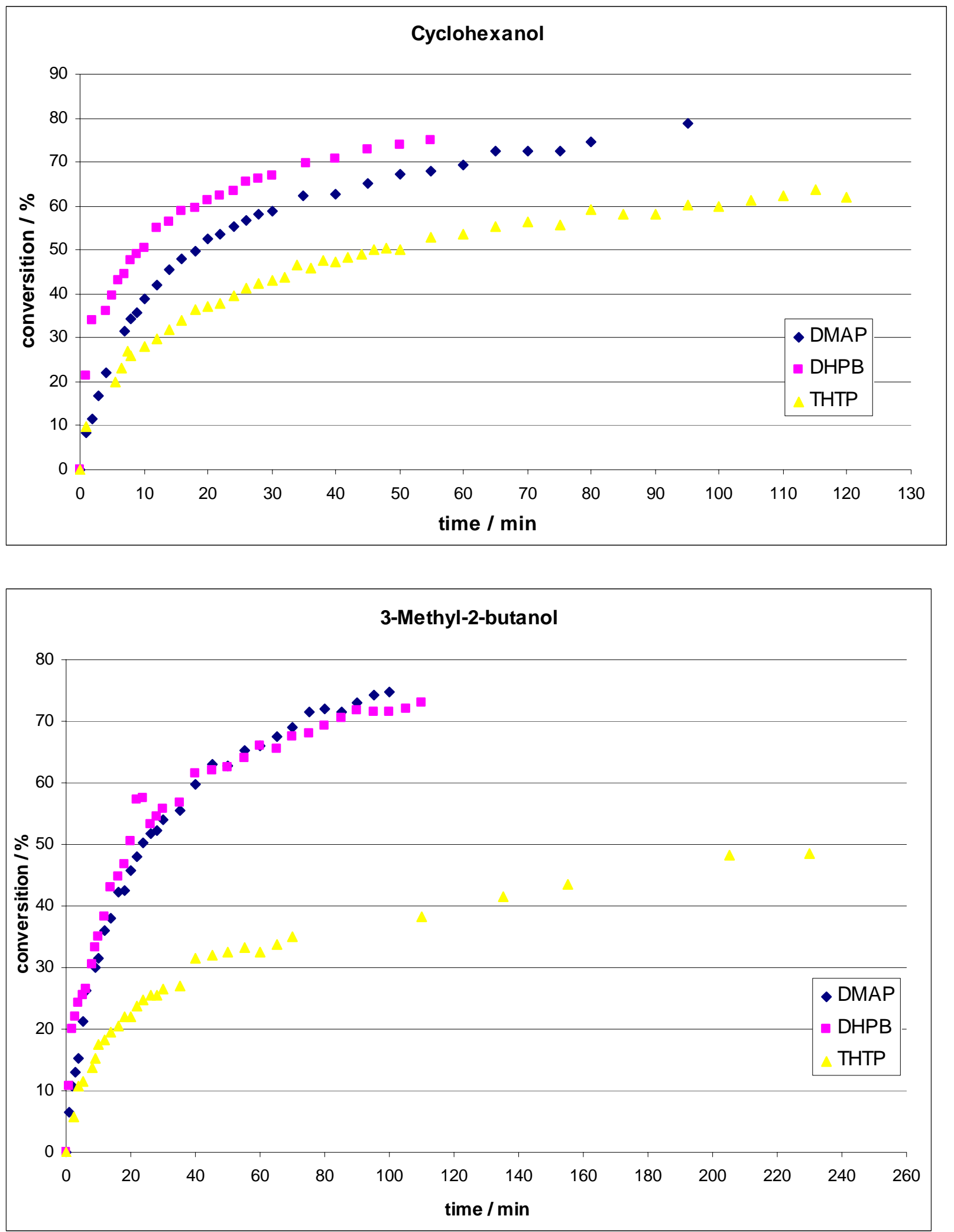


\section{ADDITIONAL REFERENCES}

${ }^{15}$ Schann, S.; Bruban, V.; Pompermayer, K.; Feldman, J.; Pfeiffer, P.; Renard, P.; Scalbert, E.; Bousquet, P.; Ehrhardt, J.-D. J. Med. Chem. 2001,44, 1588.

${ }^{16}$ Prepared according to the general procedure described in ref. 15. 


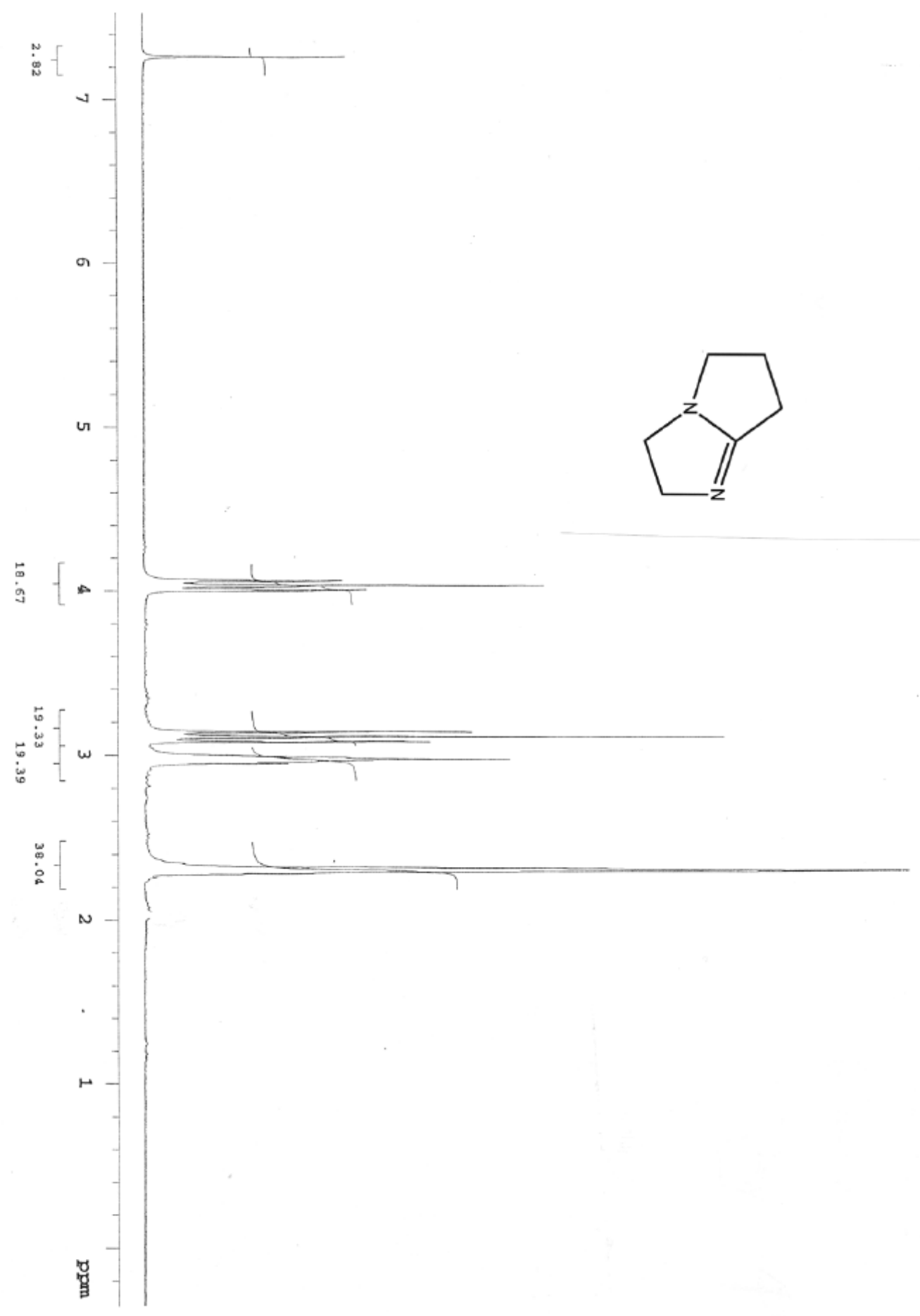




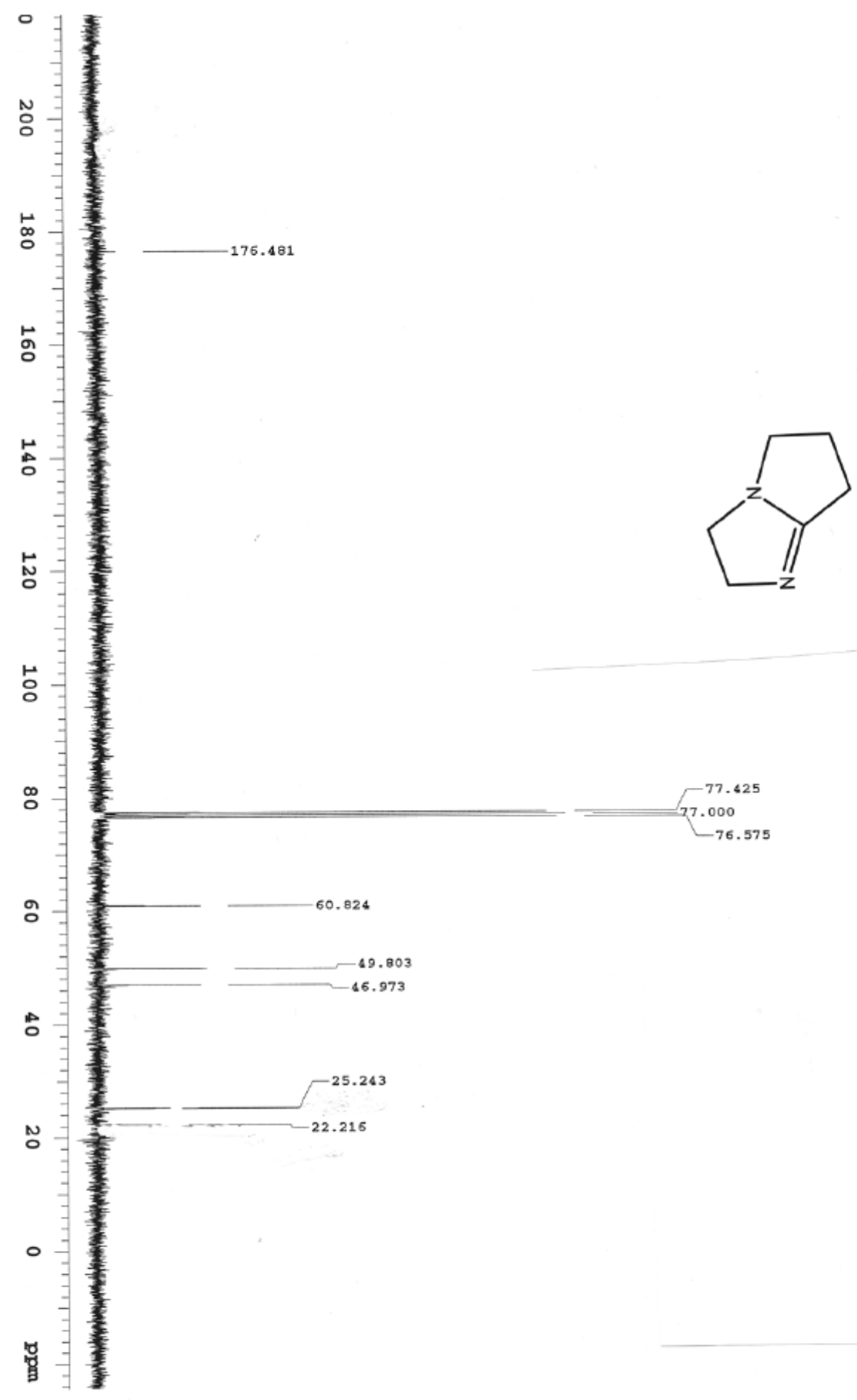




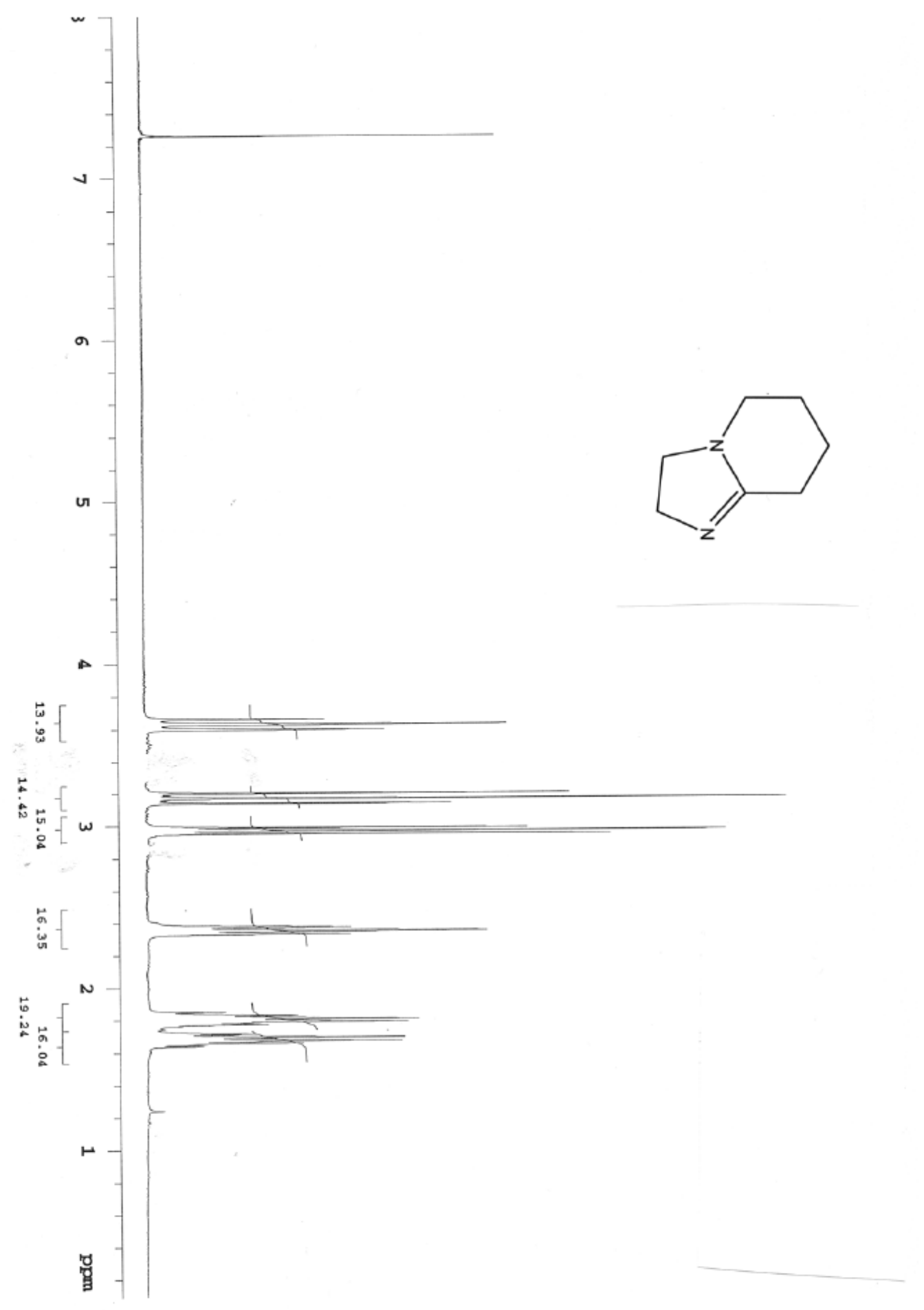




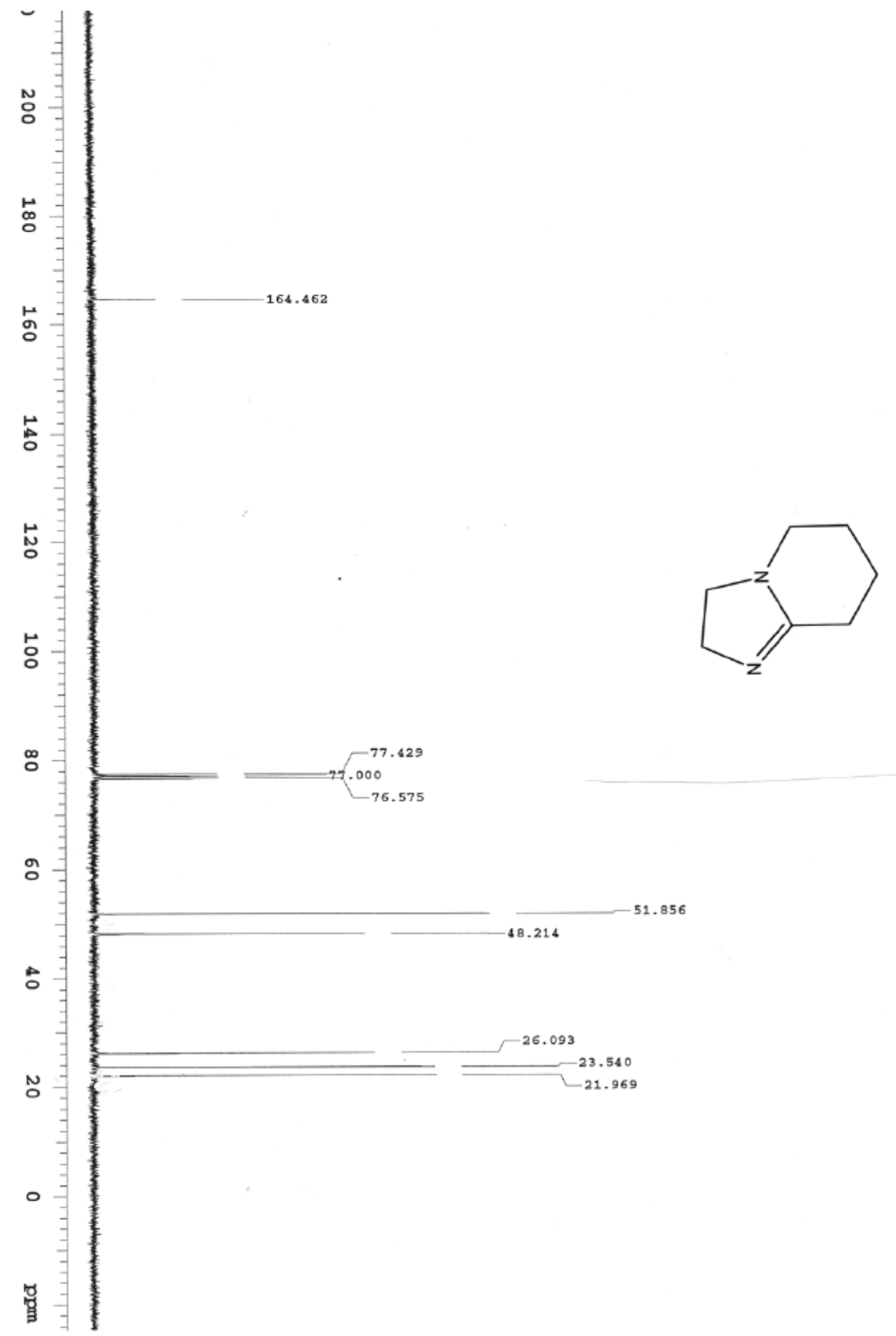




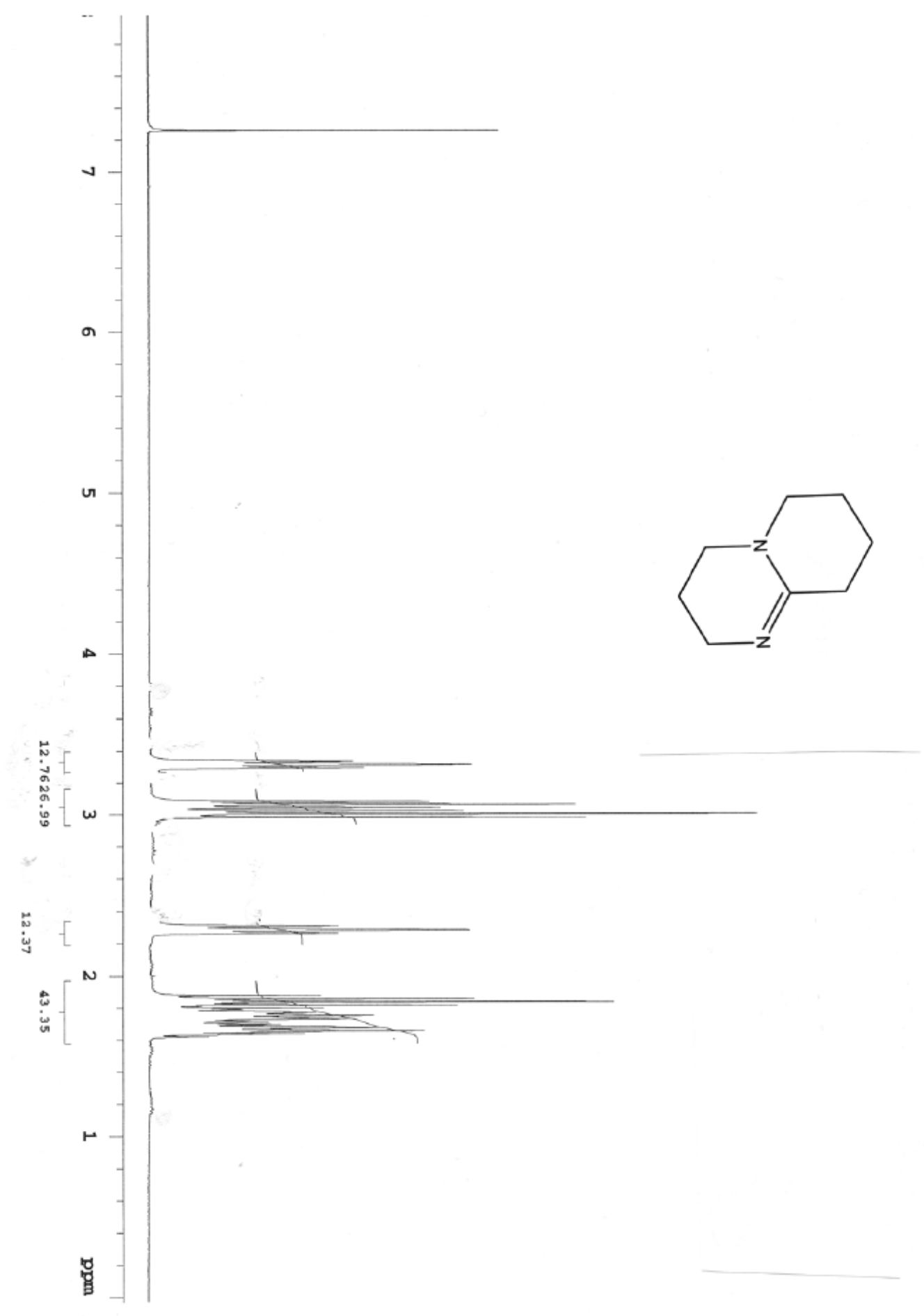



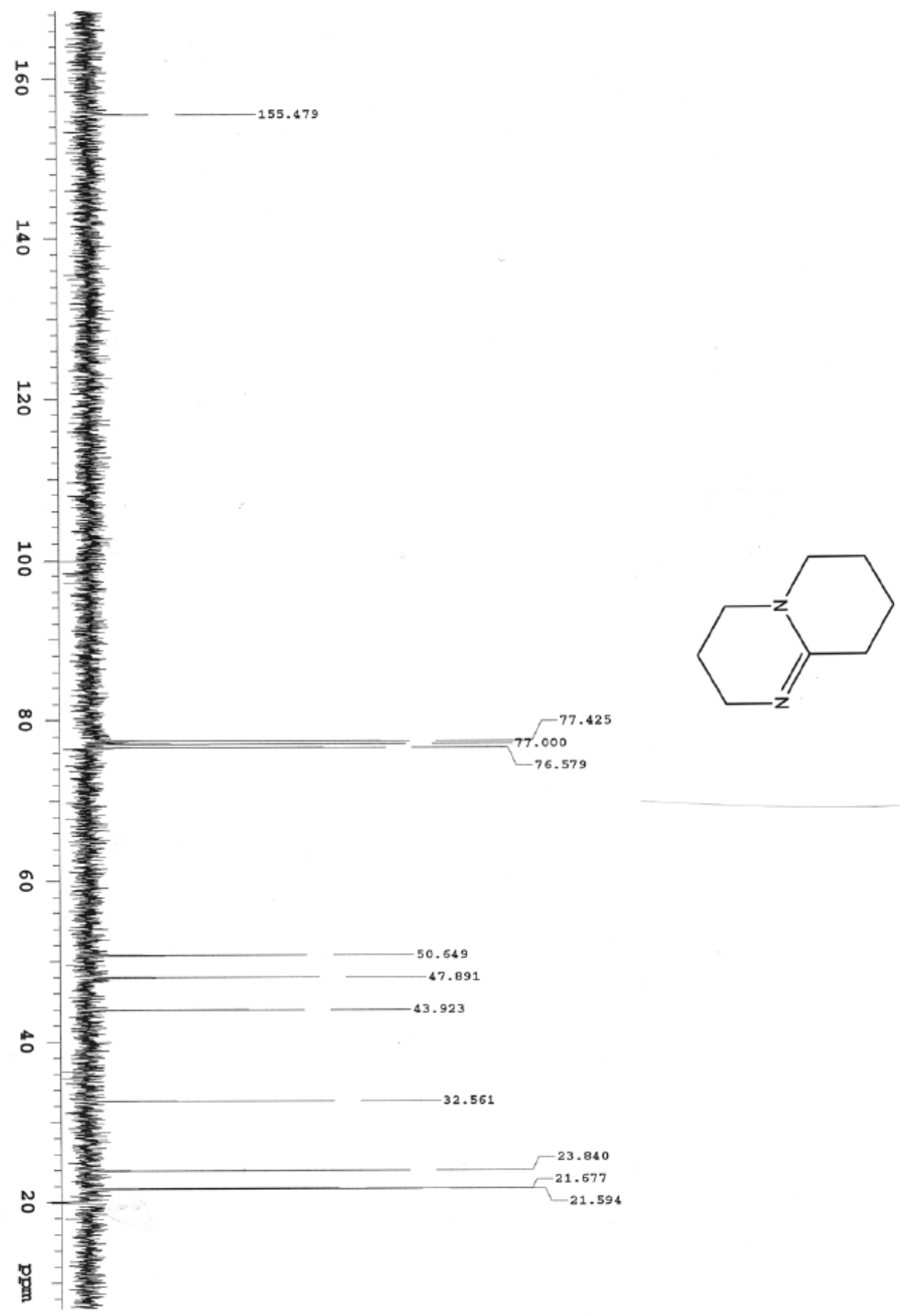


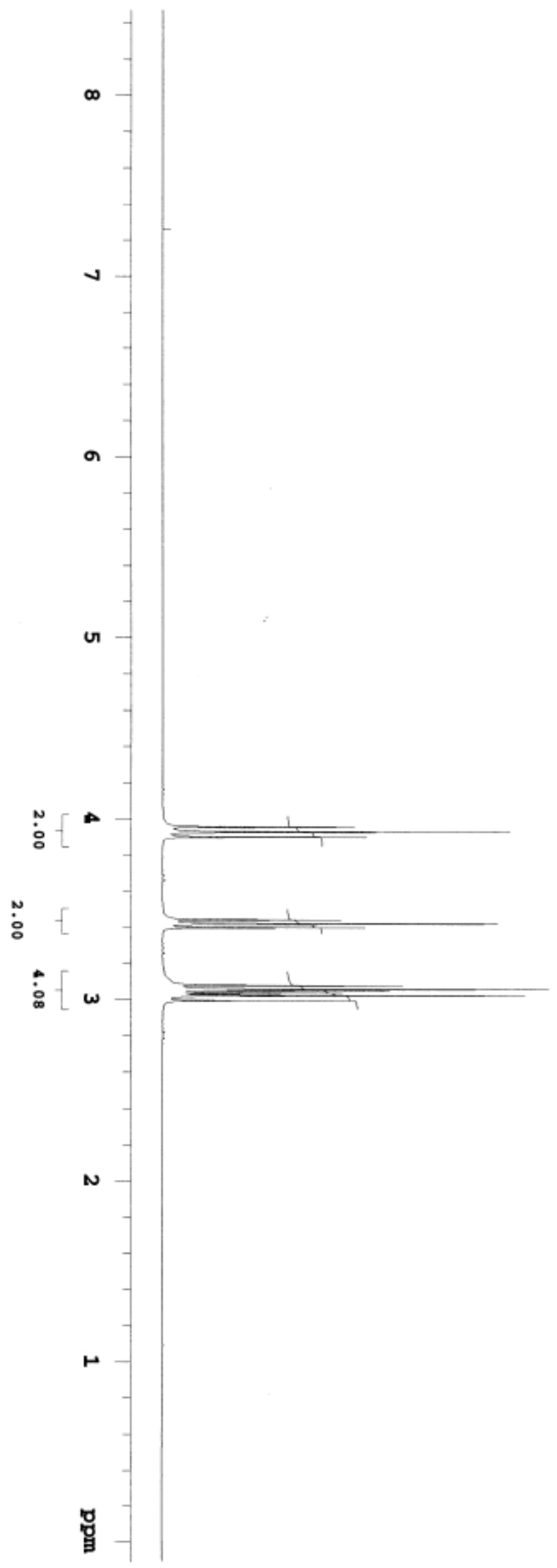




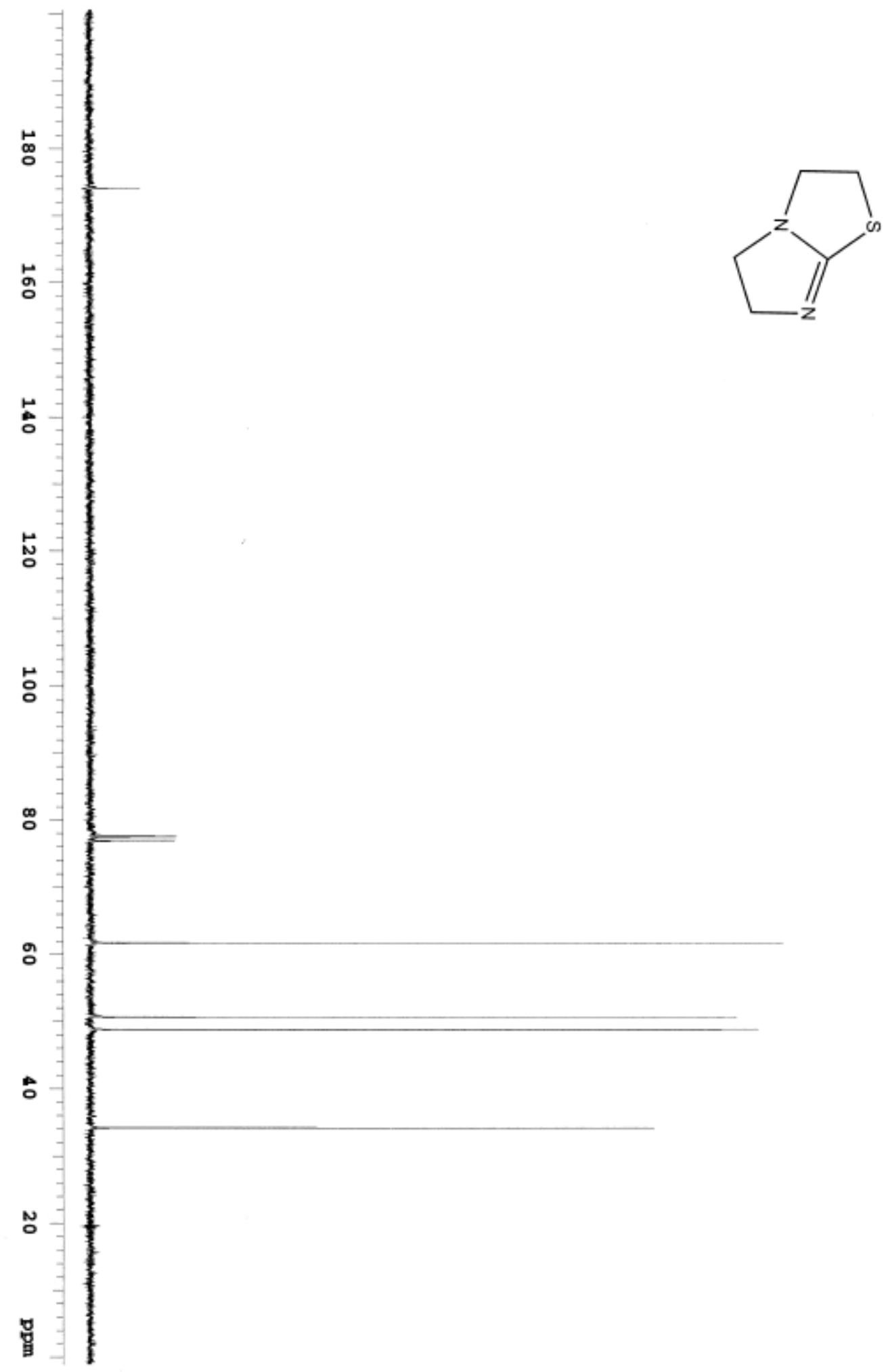




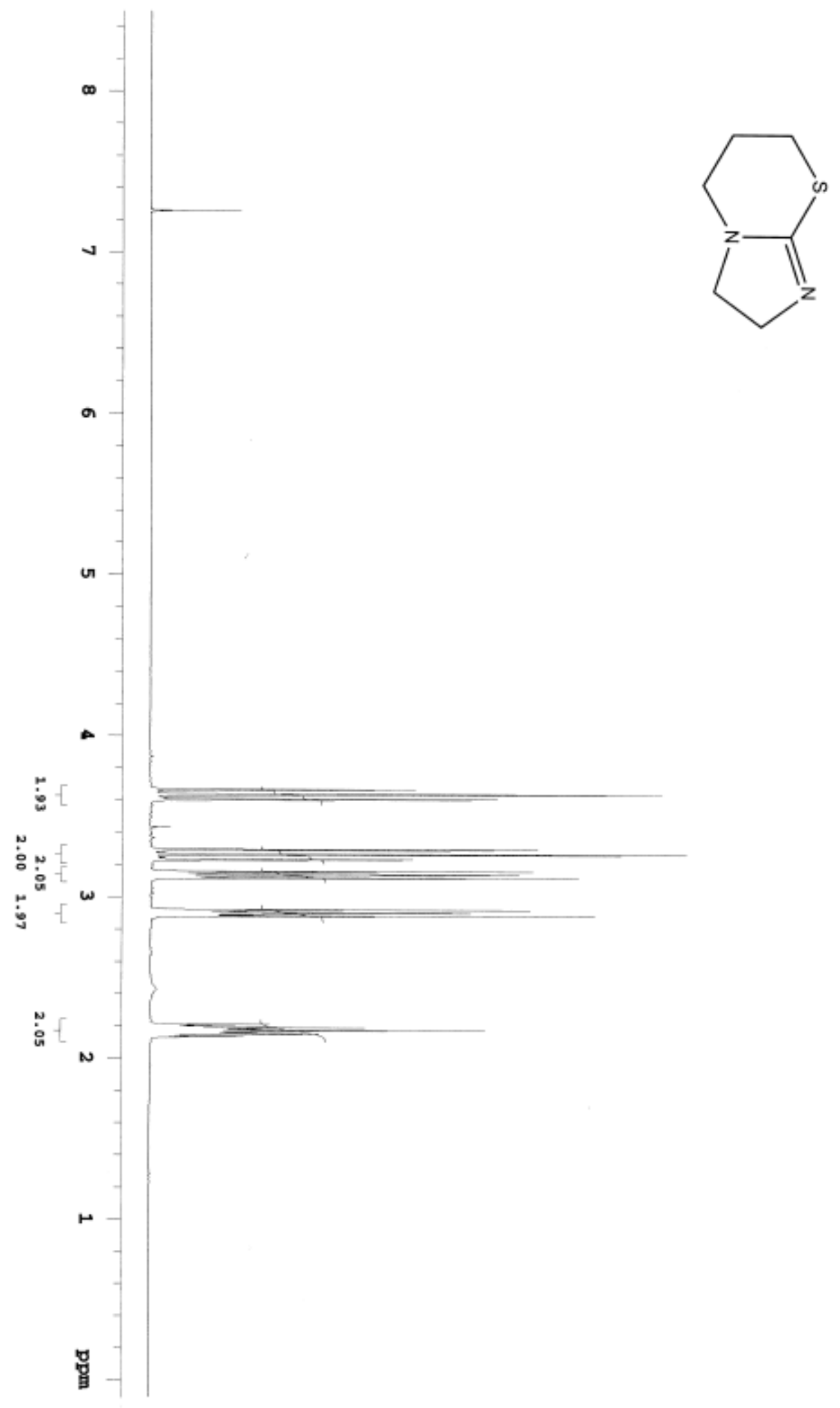



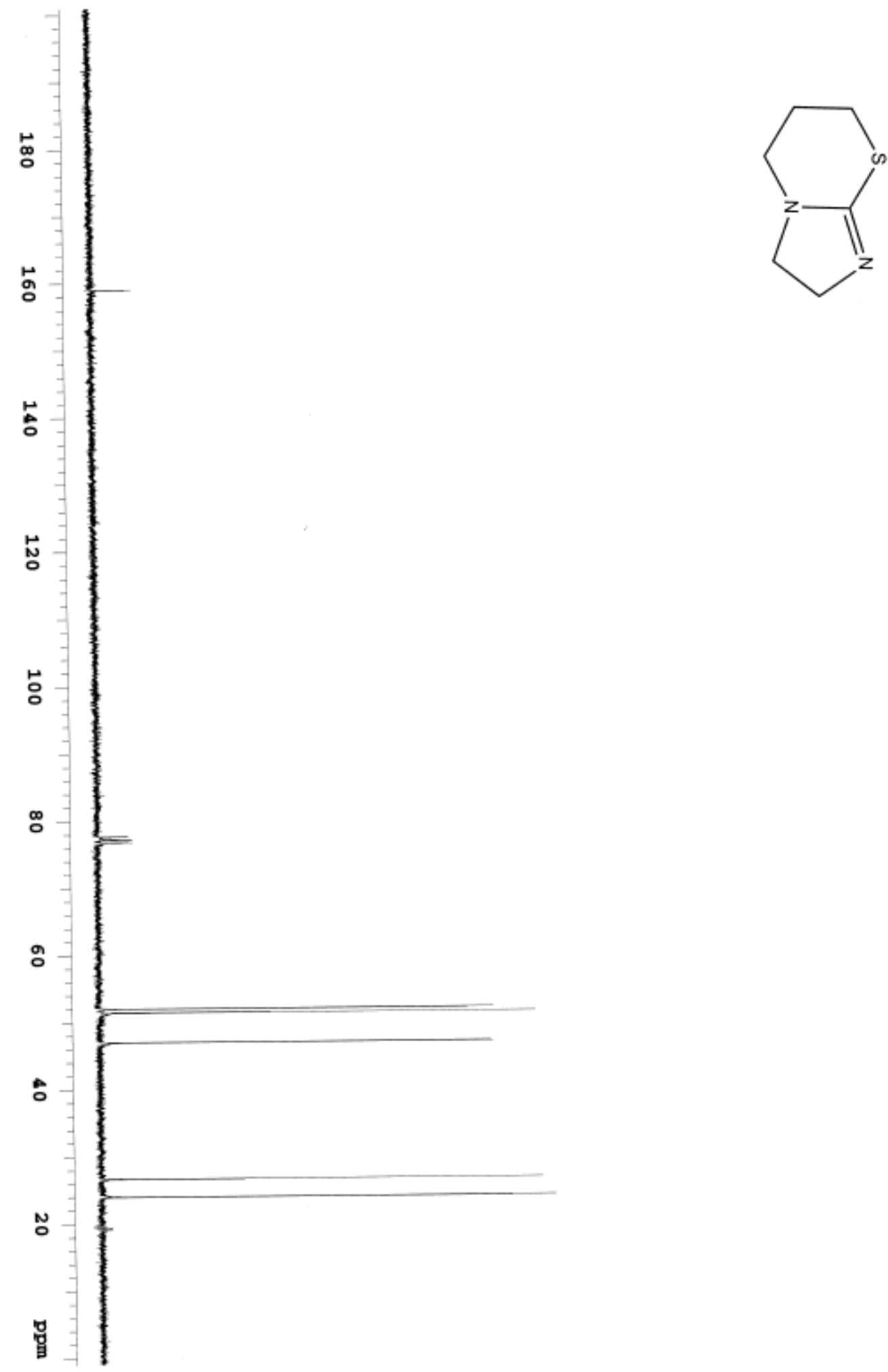

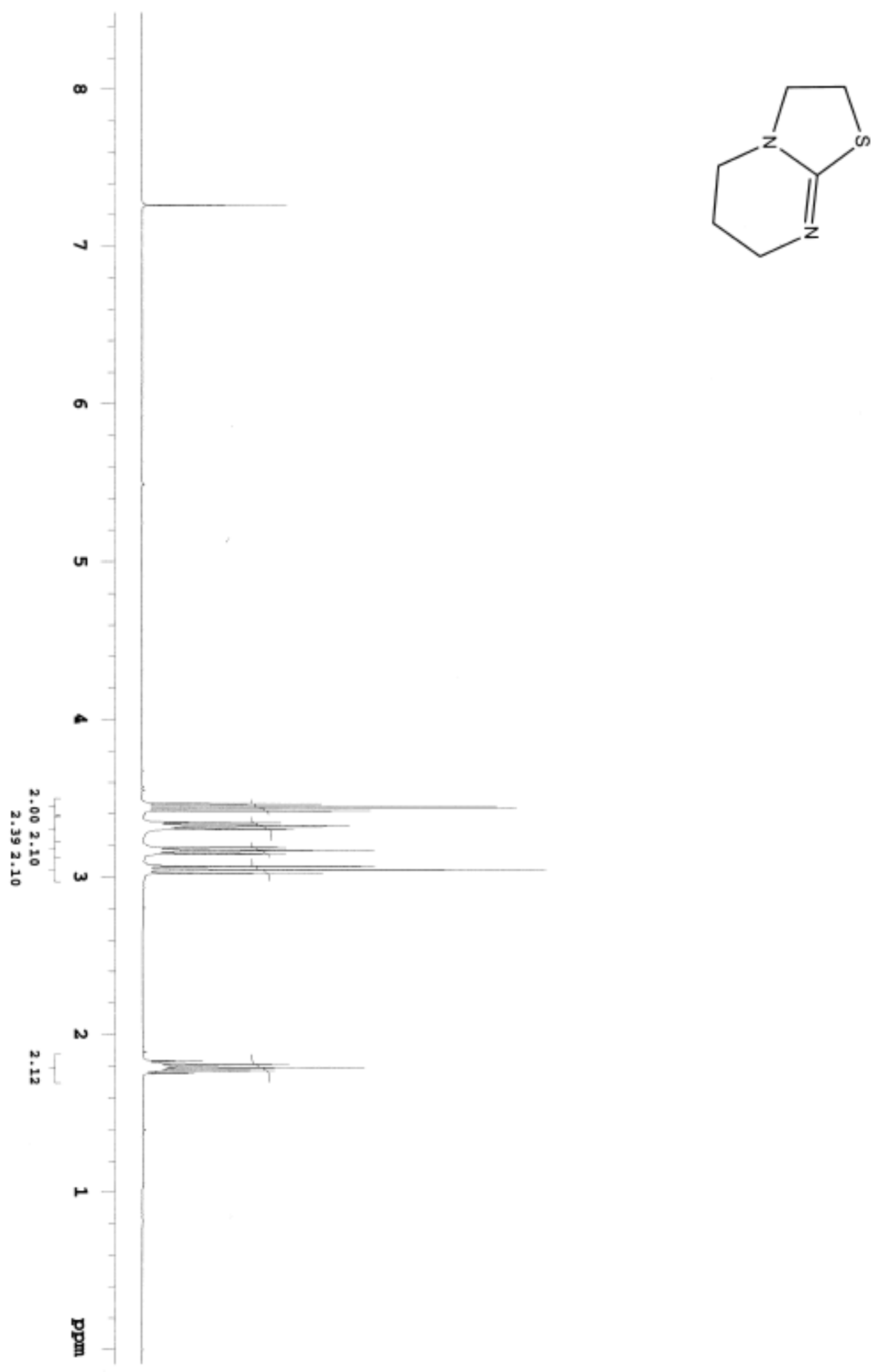

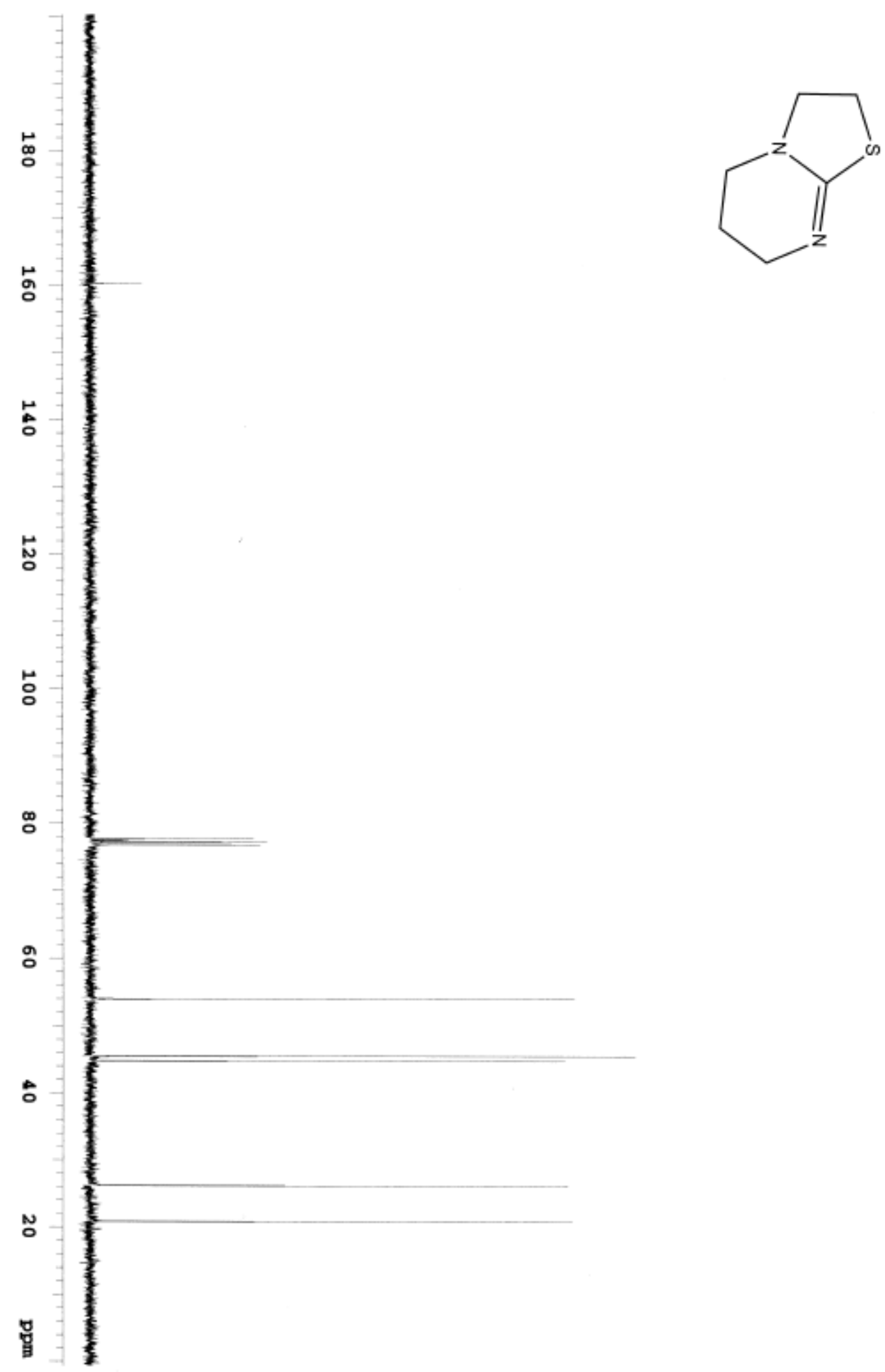

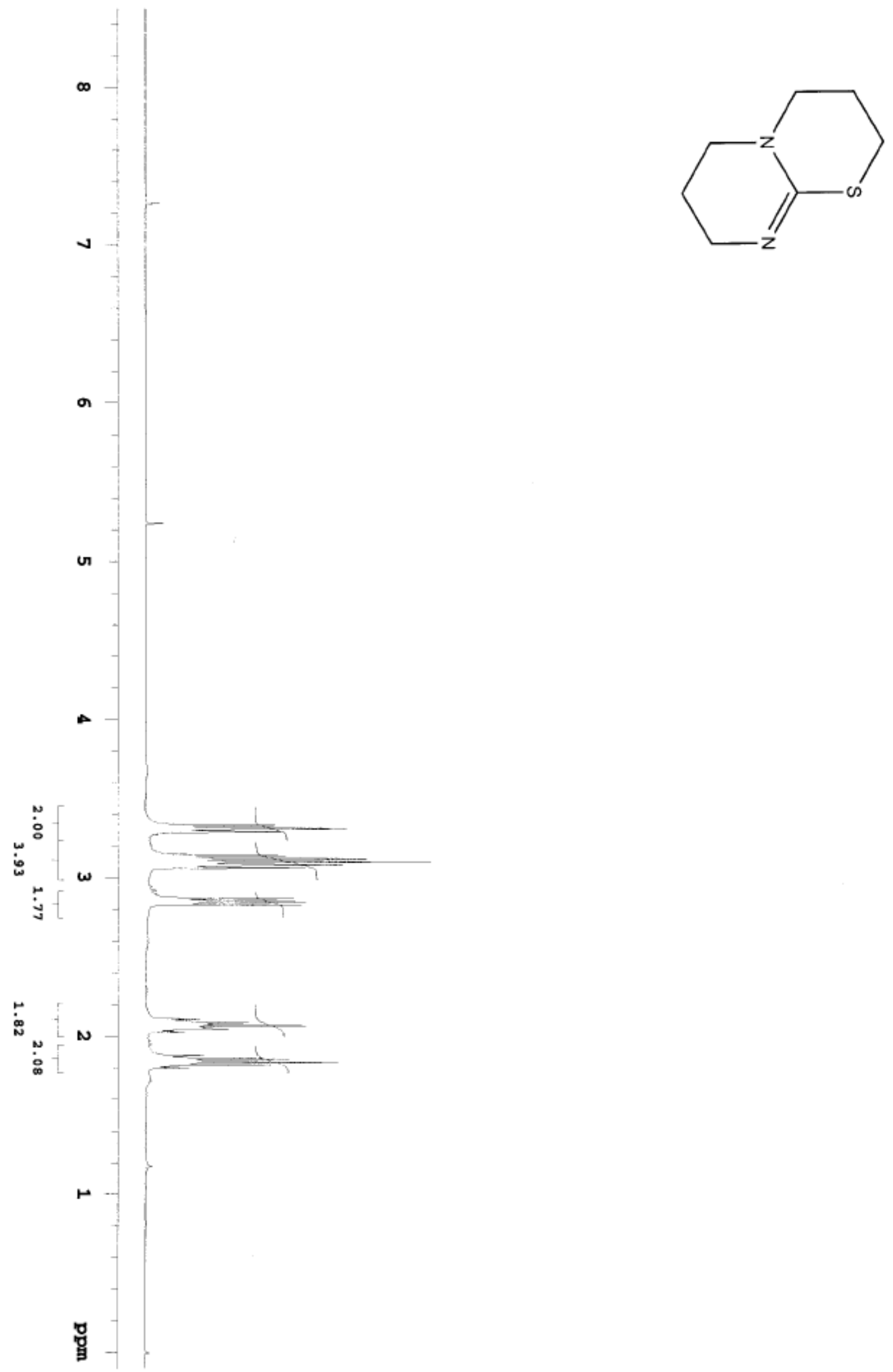

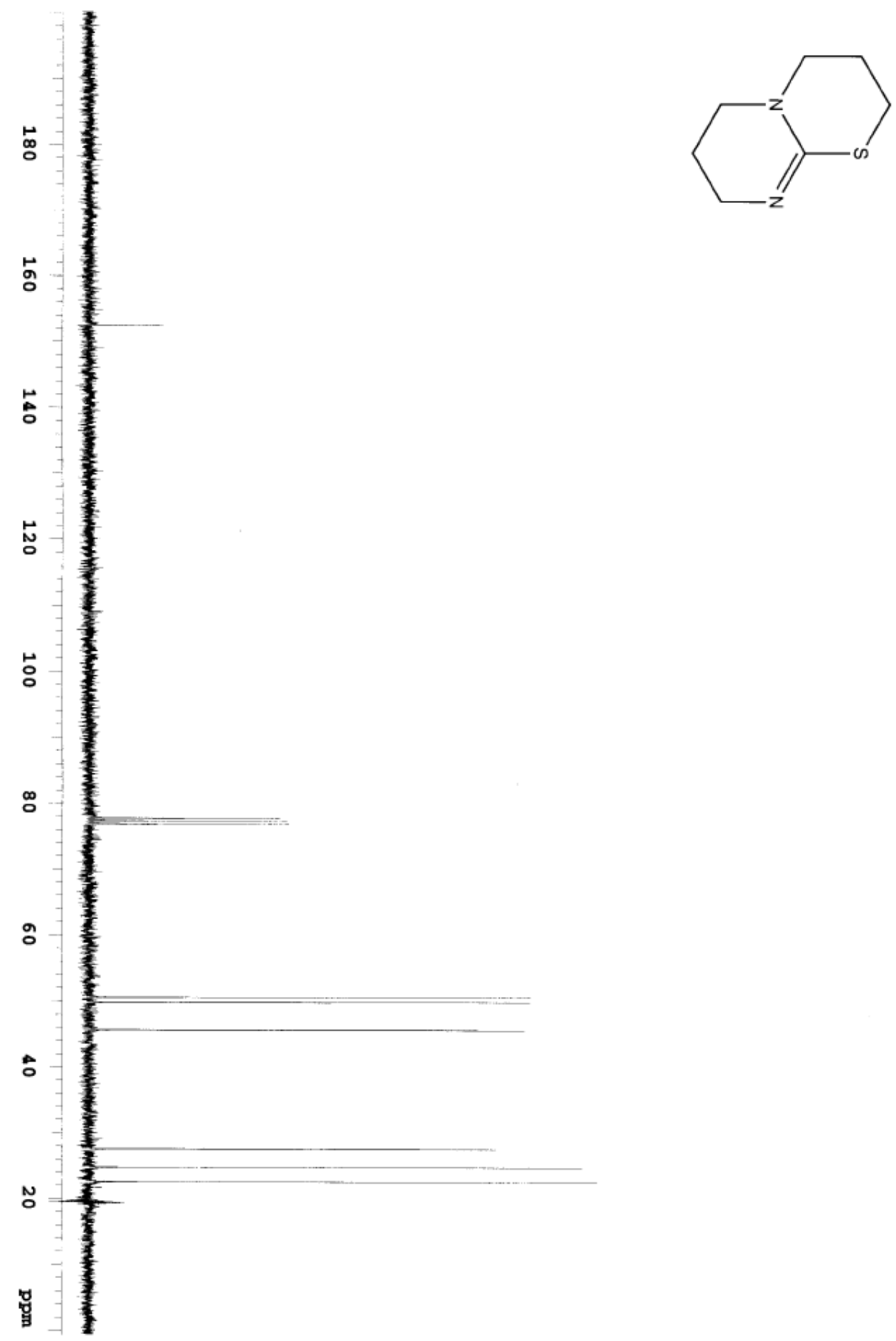

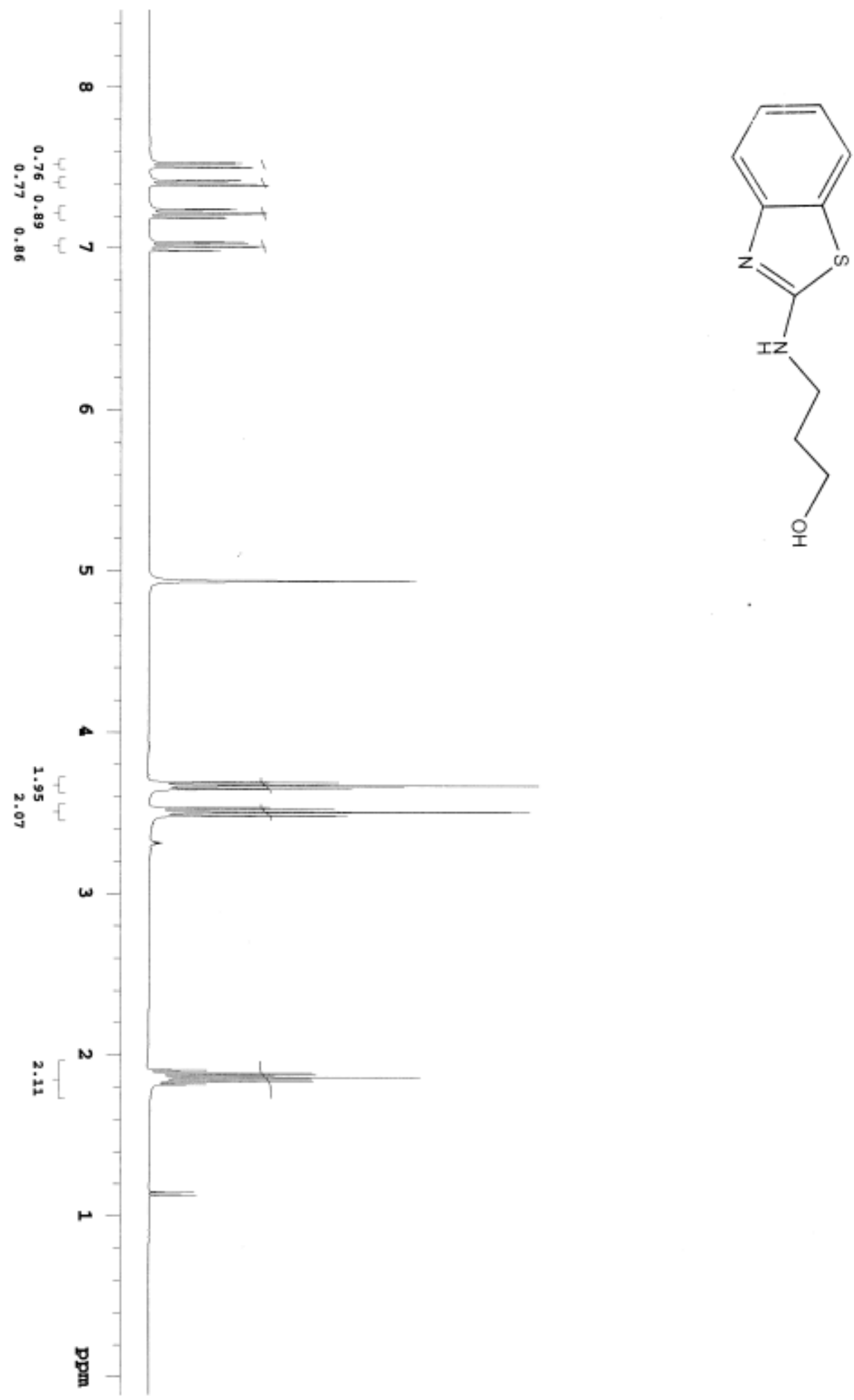

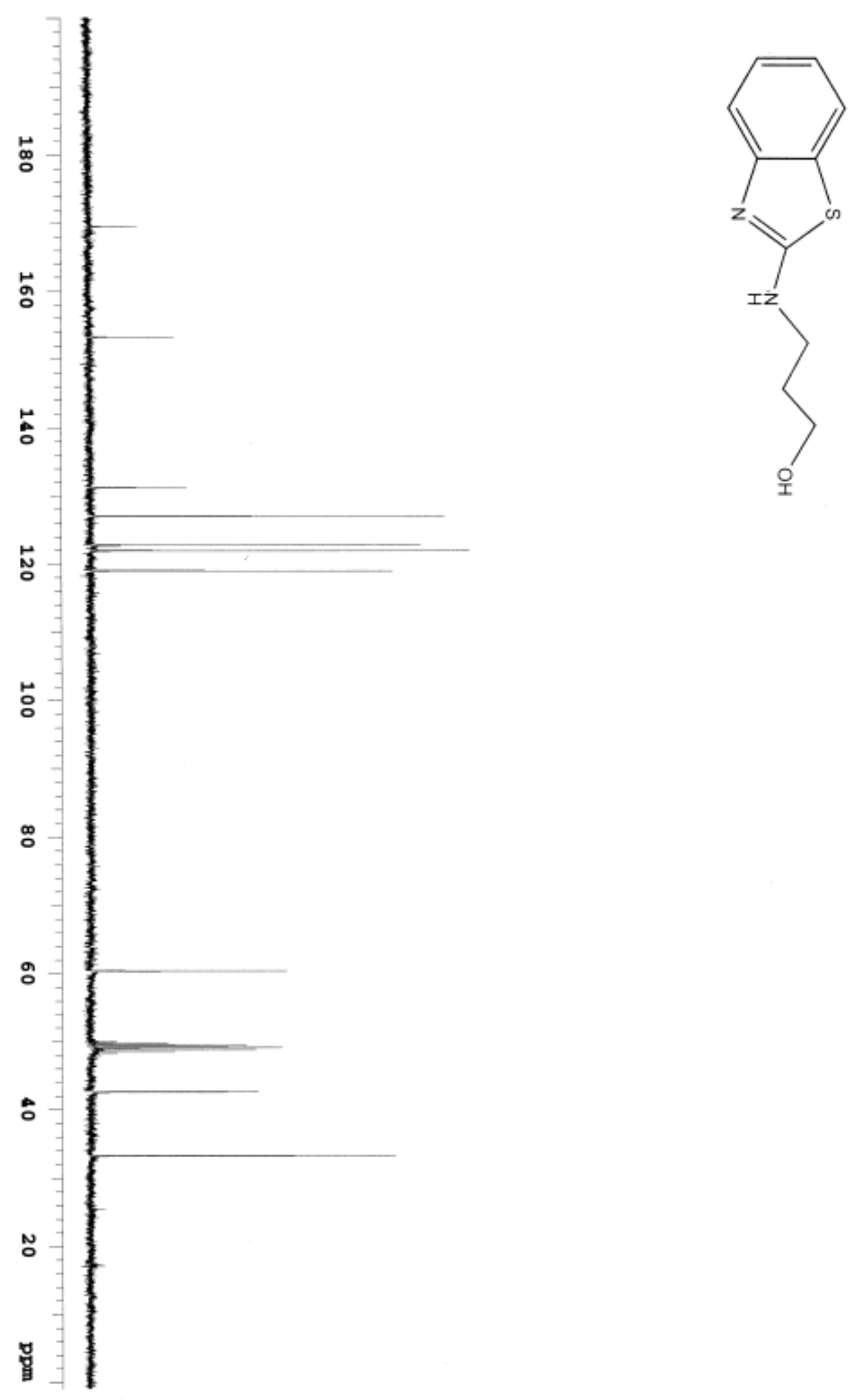

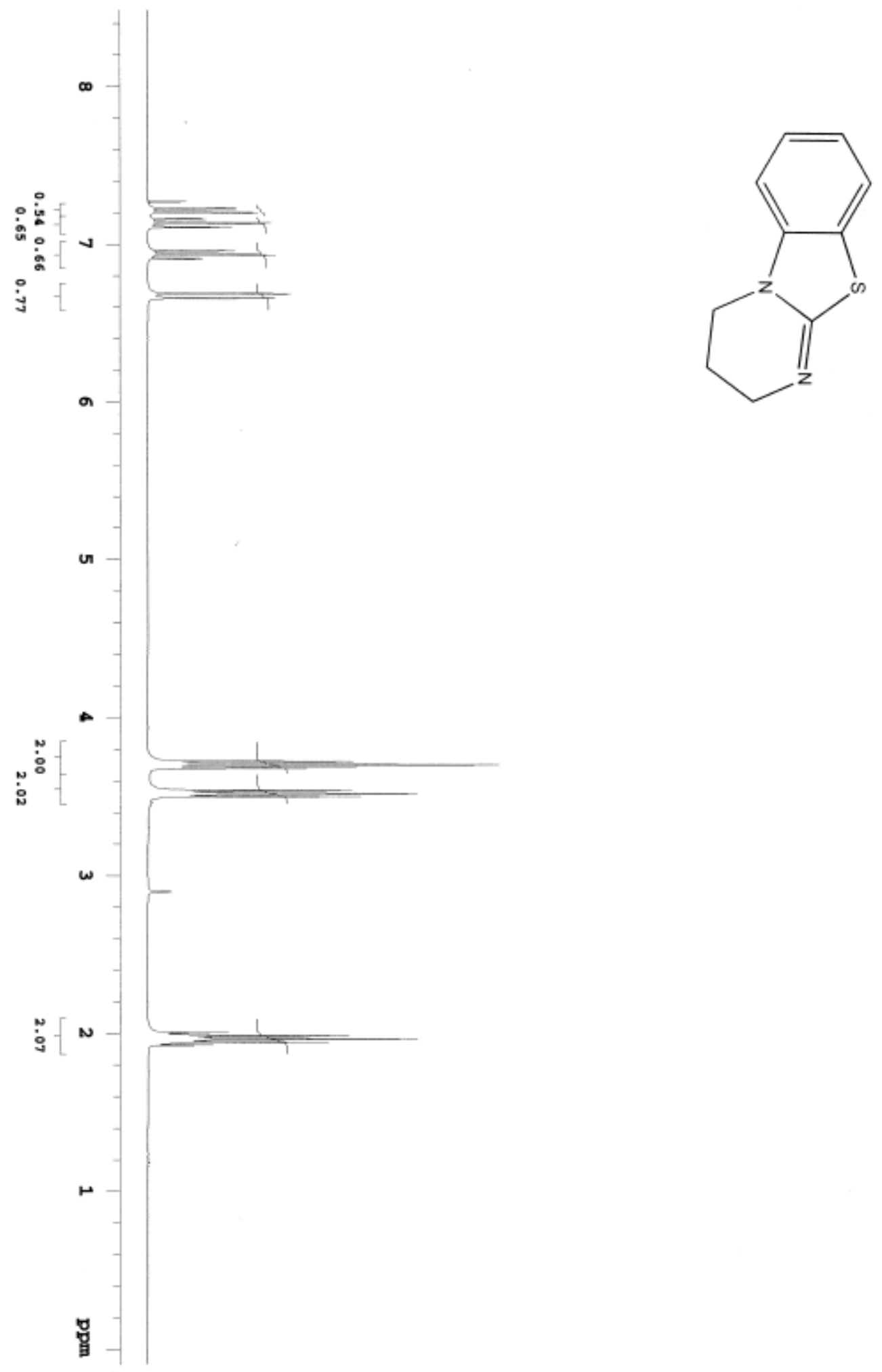

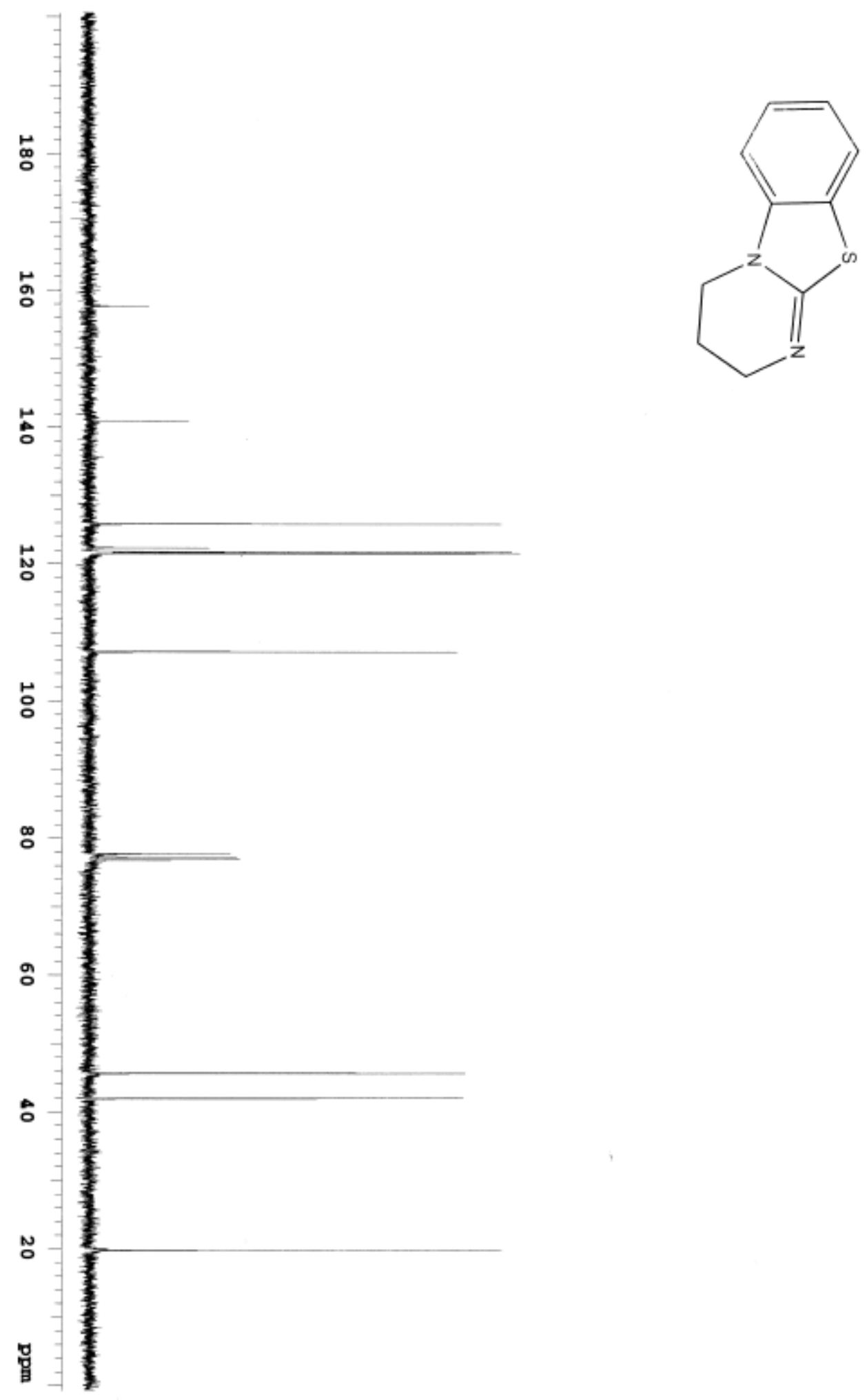